Reflection Article/Essay

\title{
The (dis)obedient occupational therapist: A reflection on dissent against disciplinary propaganda
}

\section{O terapeuta ocupacional (des)obediente: uma reflexão dissidente contra a propaganda disciplinar}

\author{
Pier-Luc Turcotte ${ }^{\mathrm{a}}$ (D), Dave Holmes ${ }^{\mathrm{b}}$ (D) \\ ${ }^{a}$ School of Rehabilitation, Faculty of Medicine and Health Sciences, Université de Sherbrooke, Sherbrooke, QC, Canada. \\ ${ }^{b}$ Faculty of Health Sciences, School of Nursing, University of Ottawa, Ottawa, ON, Canada.
}

How to cite: Turcotte, P. L., \& Holmes, D. (2021). The (dis)obedient occupational therapist: A reflection on dissent against disciplinary propaganda. Cadernos Brasileiros de Terapia Ocupacional, 29, e2924. https://doi.org/10.1590/2526-8910.ctoARF2211

\begin{abstract}
$\underline{\text { Abstract }}$
Introduction: Despite struggling to establish itself as an autonomous profession, occupational therapy remains extensively regulated and controlled by discursive authorities inside and outside the discipline. After overcoming the profession's reformist ideals, the military governance that supported its rapid expansion morphed into civil institutions but both were based on similar grounds: occupational therapists should obey a strict set of rules while disobedience and dissent are consistently repressed or silenced. Objective: The objective of this article is to deconstruct dominant (consensual) discourses that shape the status quo in occupational therapy and envision alternative paths for the development of the discipline. Method: Drawing on the work of Erich Fromm and Jacques Rancière, we propose a (critical) theoretical analysis of the concepts of disobedience and dissensus as they apply to occupational therapists. Results: The concepts of disobedience (Fromm) and dissensus (Rancière) can be used to revisit the consensus shaped by discursive authorities inside and outside occupational therapy and expose the political nature of such processes. We argue that remaining oppressive forces similar to those of a warfare regime persist in regulating occupational therapy practice and knowledge by enacting a form of 'disciplinary propaganda.' Rather than threatening the development of the discipline, disobedience and dissensus constitute critical responses to disrupt dominant discourses and give rise to healthier concepts. Conclusion: The use of politically charged terms such as disobedience or dissensus can be seen as controversial and unsettling for a profession like occupational therapy but we believe they are necessary for the future of our discipline.
\end{abstract}

Keywords: Consensus, Critical Theory, Dominance Subordination, Occupational Therapy, Politics, Social Oppression. 


\section{$\underline{\text { Resumo }}$}

Introduçáo: Apesar de lutar para se estabelecer como uma profissão autônoma, a terapia ocupacional permanece amplamente regulamentada e controlada por autoridades discursivas dentro e fora da disciplina. Depois de superar os ideais reformistas da profissão, o governo militar, que apoiou sua rápida expansão, se transformou em instituiçóes civis, mas ambos foram baseados em fundamentos semelhantes: os terapeutas ocupacionais devem obedecer a um conjunto estrito de regras enquanto a desobediência e a dissidência são consistentemente reprimidas ou silenciadas. Objetivo: $\mathrm{O}$ objetivo deste artigo é desconstruir os discursos dominantes (consensuais) que configuram o status quo na terapia ocupacional e vislumbrar caminhos alternativos para o desenvolvimento da disciplina. Método: Com base na obra de Erich Fromm e Jacques Rancière, propomos uma análise teórica (crítica) dos conceitos de desobediência e dissenso conforme se aplicam aos terapeutas ocupacionais. Resultados: Os conceitos de desobediência (Fromm) e dissenso (Rancière) podem ser usados para revisitar o consenso formado por autoridades discursivas dentro e fora da terapia ocupacional e expor a natureza política de tais processos. Argumentamos que as forças opressivas remanescentes semelhantes às de um regime de guerra persistem na regulamentação da prática e do conhecimento da terapia ocupacional por meio de uma forma de 'propaganda disciplinar'. Em vez de ameaçar o desenvolvimento da disciplina, a desobediência e o dissenso constituem respostas críticas para interromper os discursos dominantes e dar origem a conceitos mais saudáveis. Conclusáo: $\mathrm{O}$ uso de termos politicamente carregados, como desobediência ou dissenso, pode ser visto como controverso e inquietante para uma profissáo como a terapia ocupacional, mas acreditamos que sejam necessários para o futuro de nossa disciplina.

Palavras-chave: Consenso, Teoria Crítica, Dominaçáo-Subordinaçáo, Terapia Ocupacional, Política, Opressão Social.

While, according to the Bible, human history began with an act of disobedience - Adam and Eve - while, according to Greek myth, civilization began with Prometheus' act of disobedience, it is not unlikely that human history will be terminated by an act of obedience, by the obedience to authorities who themselves are obedient to archaic fetishes of "State sovereignty," "national honor," "military victory," and who will give the orders to push the fatal buttons to those who are obedient to them and to their fetishes (Fromm, 1981, p. 51).

\section{Introduction}

Over its history, occupational therapy has struggled to establish itself as a profession independent of other health disciplines. Despite the increasing autonomy observed during the past decades, our discipline is still heavily regulated (Freeman et al., 2009). Our practice is controlled by various discursive authorities stemming from the sociopolitical, economic, professional, and historical structures in which we navigate (Farias \& Rudman, 2019b). Many occupational therapists today work in centralized and impersonal bureaucratic environments (Aldrich \& Rudman, 2020), each imposing their own regimes 
of rules, norms and truths. These regimes are often enforced not only through rigid curricula and programs (education sector) and standardized clinical protocols (practice settings) but also more subtly using a variety of techniques (audits, inspections, surveillance, etc.) drawn from regulatory bodies and all-encompassing managerial procedures imposed by organizations (Freeman et al., 2009, p. 118). In regulated contexts like these, occupational therapists could easily become alienated by the systems in which they practice, in which case they would see their own actions as "an alien power" standing over - and sometimes against - them (Fromm, 1981). This may explain the feeling of dissonance among occupational therapists who struggle to safeguard quality care while also meeting accountability expectations deriving from the multiple authorities over their practice (Freeman et al., 2009). If they do not pay close attention to the level of freedom they can exercise, it may be more difficult for occupational therapists to see how existing regimes may be unequal or oppressive, and how they may be perpetuating them.

In addition to being ostensibly regulated at the institutional level, occupational therapists experience a subtler, more insidious form of regulation that stems from dominant discourses imposing their own boundaries within our practice (Hammell, 2011). Despite purporting to promote diversity in knowledge development, some authorities in occupational therapy often impose dogmatic ways of thinking not only by establishing rigid and hierarchical knowledge development processes through evidence-based discourse (Bennett \& Bennett, 2000) but also by the exclusive use of occupation-based theories (Hammell, 2009a). As it seeks autonomy, occupational therapy seems unable to develop itself due to powerful discourses that replicate a biomedical hegemony while adopting neoliberal values (Farias \& Rudman, 2019a). In response, various critics have called for a socially transformative agenda, challenging our discipline to: 1) embrace a political understanding of human occupations that are embedded within broader cultural, social and historical structures (Pollard \& Sakellariou, 2017), and 2) dissociate itself from traditional biomedical, individualistic and neoliberal discourses (Farias \& Rudman, $2019 b$ ). Criticizing the external discourses that delineate the borders of our discipline is certainly difficult but it is not the most challenging task. Occupational therapy is not only regulated from the outside, it is also controlled from within, by occupation-based models and theories (Reid et al., 2019) imposing their own regimes of truths. We believe that these discourses are now paralyzing the profession by impeding it from undertaking socially transformative practices.

Considering the apparent consensus related to this trend (Clark, 2006; Hammell, 2011; Rudman et al., 2008), our collective task is to interrogate and challenge the political, managerial and professional processes that regulate the practical and theoretical boundaries within which we practise. The objective of this article is to deconstruct dominant discourses that shape the status quo in occupational therapy. As this deconstruction cannot be theorized by staying within the boundaries of our discipline, occupational therapists may need to mobilize politically charged concepts that disrupt the current status quo. To this effect, we propose a (critical) theoretical analysis of the concepts of disobedience and dissensus in order to envision alternative paths for the future of the discipline. Because occupational therapists have not been socialized to disobey or dissent, using such terms may seem uncomfortable, perplexing and unsettling. However, they might be necessary. We turn to the work Fromm (1981) and Rancière (2010), who respectively theorized disobedience and dissensus. While this paper does not propose concrete ways to practice 
disobedience or dissensus in occupational therapy, it is intentionally written provocatively and, in line with our theoretical perspectives, could be read as an enactment of disobedient thought or a form of dissensus.

\section{Situating Our Analysis}

In this paper we propose disobedience and dissensus as critical responses to the consensual discourses in vogue in occupational therapy. We situate ourselves as queer French-speaking academics in a North American context, whose dissatisfaction with the status quo in occupational therapy motivated our analysis. This analysis draws on the work of two Continental philosophers, Erich Fromm and Jacques Rancière, both exponents of critical social theory. Because not everyone may be familiar with their work, this section first introduces critical social theory and defines the concepts used in this paper.

\section{Critical social theory}

The term Critical Social Theory (or critical theory) emerged from the Frankfurt School in the 20th century and is now associated with scholars from a wide range of disciplines. While early research in this tradition focused on class oppression, recent work stressed the interconnections between class, gender, race, and sexual orientation (Buchanan, 2010). According to Guba \& Lincoln (1998), critical theory is a paradigm inclusive of perspectives such as feminism, neo-Marxism, queer studies, and postmodernism (poststructuralism, postcolonialism, anticolonialism). As opposed to the dominant postpositivist paradigm, a critical theory perspective also allows occupational therapy scholars to be cautious about the notions of 'truths', evidence, and reality. Drawing on historical realism, critical theory assumes that reality not only exists 'virtually' but is also precisely located within historically situated social, political, cultural, economic, ethnic and gender structures. This historical situatedness allows critical researchers to generate knowledge that erodes misapprehension and stimulates actions with a view to tackling social inequalities. In this context, critical research explicitly aims to transform the social structures that exploit and oppress other humans. Critical theoretical perspectives have become more and more popular in the field of health sciences, such as nursing (Holmes \& Gagnon, 2018; Holmes et al., 2006a, 2008), physiotherapy (Eisenberg, 2012; Nicholls, 2017) and occupational therapy (Farias et al., 2019c; Gerlach et al., 2018; Rudman, 2012; Rudman \& Aldrich, 2016). However, the concepts developed by Erich Fromm and Jacques Rancière have not yet been mobilized. Their concepts of disobedience (Fromm, 1981) and dissensus (Rancière, 2010) can be used to deconstruct the consensus drawn by discursive authorities in our discipline and expose the political nature of such processes.

\section{Fromm and disobedience}

As a sociologist and psychoanalyst, Erich Fromm is one of the first representatives of the Frankfurt School and his philosophical work belongs to Continental thought. His work could certainly be helpful to anyone who studies the notions of (dis)obedience and (non)conformity to prevailing regimes of truth. In his essay On Disobedience, Fromm (1981), puts into practice his disobedience to received wisdom and official political 
thought, as well as his obedience to healthy thought, i.e. thought that will ensure the survival of humanity. Of particular interest is Fromm's rejection of a conception of 'health' that is grounded in conformity to a given social order and of 'pathology' as a lack of adjustment to that order. While disobedience is often thought of as a radical or extreme response to an unequal or inhumane situation, the enactment of disobedient thought is much subtler and subversive, theoretical but no less practical for that. Fromm's definition of disobedience strays away from the reductionist 'transgression of the law' and is inclusive of subtleties inherent in the resistance to dominant regimes of norms, rules or truths. In order to understand disobedience, we must first deconstruct what is meant by 'obedience.' Fromm introduces two types of obedience: 'heteronomous' obedience implies submission and abdication of one's autonomy to an institution or power external to oneself, whereas 'autonomous' obedience refers to an affirmation of oneself and one's beliefs and convictions. As such, conforming solely to dominant authorities (heteronomous) and rejecting one's own convictions (autonomous) may ultimately result in unhealthy thought. While Fromm designates these two types of obedience as binary, this distinction needs to be expanded more precisely with regards to the concepts of conscience and authority, both of which are helpful in guiding attempts to either obey or disobey.

Fromm (1981) describes two forms of conscience: the 'authoritarian' conscience and the 'humane' conscience. The authoritarian conscience is the internal voice of an authority (superego) which we must obey, such as the commands and prohibitions of the father accepted by the child. Although this power can be internalized, the authoritarian conscience presupposes obedience to an external power. The humane conscience (id), on the other hand, is the voice present in every human being, independent of external sanctions or rewards; it is based on the feeling of what is beneficial to human life (humane) and what is prejudicial to it (inhumane). In addition to conscience, authority has two meanings in Fromm's work (1981): 'rational' and 'irrational' authority. A good example of rational authority would be the teacher/student relationship. In the best case, the interests of teacher and student head in the same direction: if the student succeeds, the teacher is also successful, and so on. The current academic context sometimes converts this relationship into something that is not rational, where the interests of the teacher precede those of the student. This case would correspond to another type of authority - irrational authority - such as that exemplified in the master/slave relationship. The interests of slave and master are intrinsically opposed: the more exploited the slave is, the better off the master will be. While rational authority is intrinsically equal, irrational authority fundamentally depends on inequality since what is beneficial for one is necessarily detrimental to the other. Because nobody would agree to be exploited if they knew it could be avoided, irrational authority relies mostly on force or suggestion.

Both types of authority are present in our discipline, sometimes in an institutionalized (rules, norms, etc.), sometimes in a symbolic (values, identity, etc.) form. While Fromm's terminology may seem to be framed according to a binary logic, those categories are not fixed or rigid but should be understood as fluid and constantly changing, with all the complexities that arise in the contexts in which they are engaged. In some contexts, what seemed to be a humane conscience can morph into an authoritarian conscience (e.g. actions driven by selfinterest), and a rational authority in one context can become irrational in another (e.g. the teacher/student relationship cited above). It is not the aim of this article to provide concrete ways to practice disobedience; in fact, we argue that remaining at the theoretical level is 
already a way of practising disobedience in a profession like occupational therapy. Without offering a roadmap per se, we try to articulate examples of situations in which dominant discourses may become oppressive and illustrate a number of possible avenues in which disobedient thought may be necessary and healthy. In this case, disobedience should be understood not as an individual endeavor but more as a collective and ongoing act of liberation. As Fromm (1981, p. 48) puts it, the idea of disobedience, "[...] even if embodied in one person, gains social significance only if it is embodied in a group". For him, a social order should aim for the development of the psychological qualities needed to realize all humans' potentialities, such as creativity and critical thinking as well as differentiated emotional and sensual experiences. Seen in this way, a collective enactment of disobedience is complementary to Rancière's notion of dissensus.

\section{Rancière and dissensus}

Though it is difficult to affiliate it with any mainstream philosophical strand, the seminal work of Jacques Rancière emerged in the 1960-1970s and was consecutively associated with other French Continental philosophers like Foucault, Althusser, Deleuze/Guattari, Bourdieu, and Lyotard (Deranty, 2003). His work is still influential today and contributed to the understanding of sociopolitical domination and emancipation (Browning, 2010). Rancière's thought will be helpful in addressing the political process underlying the construction of consensus in occupational therapy and how it rejects marginal forms of knowledge (later referred to as 'dissensus'). Before introducing the concept of dissensus, we must first address how dominant discourses (consensus) rely on dogmatic ways of thinking which suppress expressions of dissent. In his essay Dissensus: On Politics and Aesthetics, Rancière (2010) shows how political consensus is nothing less than an esthetic regime - a configuration (or distribution) of what is perceptible (sensible) or not. In our discipline, this regime of esthetics is reinforced to ensure that what is perceived about occupational therapy (discourses, practices, etc.) corresponds to the dominant consensus and that any oppositional viewpoints are silenced or made invisible (Beagan, 2020; Grenier, 2020; Kiepek et al., 2019).

To understand the perils of dogmatic ways of building consensus, Rancière introduced the notions of 'police' and 'politics' (Deranty, 2003). Distinct from the common notion of cops on the street, Rancière's concept of police "[...] defines the allocation of ways of doing, ways of being, and ways of saying" (Rancière, 1998, p. 29). The police order, therefore, corresponds to the organization of society, the hierarchical and contingent division and distribution of the various parts that make up the social whole, ensuring that each part occupies the place and function to which it was assigned (Gourgues, 2013). Any police order thereby determines who has a part in society and who does not. Rancière (1998) argues that the police order is morally wrong and unequal because it opposes a minority gaining power and influence over the majority. However, for this type of inequality to persist requires accepting that each side is actually equal and able to understand the order in the first place, i.e. recognize the police order as unequal. In occupational therapy, the police order corresponds to the multiple processes and forces that shape the particular way one is able to take part in the profession (e.g. codes of ethics/standards of conduct, assessment protocols, disciplinary actions). Several national occupational therapy associations specifically state in their codes of ethics that they expect 
their members to support their association, even if they disagree with it [see Canadian Association of Occupational Therapists, 2018; Occupational Therapy Australia, 2014 or American Occupational Therapy Association, 2020]. According to Rancière, the political goal of the police order is to deny any form of debate and contestation in favor of overall consensus. Anything that would make the current order regress or even progress beyond a certain limit would be seen as a threat that must be eliminated or rehabilitated in order to preserve the esthetic regime. When a consensus is admitted as such, for Rancière, it is necessarily a false consensus, not only because it is not grounded in the participation of all parts but also because some parts were reduced to silence and invisibility.

On the other hand, Rancière (1998, p. 30) conceptualizes 'politics' as the moment when the 'part who have no part' challenge a political consensus in a dominant order. Rancière refers to the 'part who have no part' as those who are made invisible and who suffer from the current distribution of the sensible, the inequality and arbitrariness of the police order (Deranty, 2003). In Rancière's theory, politics means the reintroduction of disagreement and debate - a disruption of common sense and a contestation of who might speak and what there is to speak about (Rancière \& Panagia, 2000). The essence of politics lies in the concept of 'dissensus,' involving the fundamental rejection of hierarchy and the explicit presupposition of equality, in which the part who have no part already speak and act as if their speech was perceptible (sensible). The collectivization of their capacities and their investment in dissensus implies reconfiguring the social order by dismantling unique regimes of perceptions and meanings. In any consensual regime, dissensus often appears as disordered movements, making inappropriate or unreasonable demands. For example, one would never consider criticizing the evidence-based discourse in occupational therapy, at the risk of appearing regressive or unprofessional. For those who only speak the language of the status quo, dissensus may always remain unintelligible (Hewlett, 2007). But for Rancière, dissensus is not an irrational or chaotic movement of revolt, quite the opposite. It allows for the part who have no part to exist as if they were nothing but equal. There is a 'part who have no part' in every discipline and the collective task is to seek these voices in order to re-establish equality. By radically disrupting the inequality of consensual discourses that stabilize the status quo, dissensus necessarily involves some form of initial (symbolic or real) violence through the formation of polemical spaces (Rancière, 2009). Rancière uses the term 'violence' here mainly to show how dissensus and polemical spaces can be viewed by those who can only accept and defend the status quo. In fact, it is only through these scenes of enunciation that silenced, marginalized, dissenting, or oppositional voices can ultimately express themselves.

In attempting to deconstruct dominant discourses in occupational therapy, it could be useful to return to the thought of Fromm and Rancière and put their concepts into dialogue. Their notions of disobedience and dissensus each constitute critical responses to either irrational authority or the hierarchical police order that subjugates or silences certain voices to maintain conformity or the esthetic regime in place. While there are some similarities in their concepts, their respective approaches to the notions of 'conscience,' 'authority' and 'the part who have no part' are particularly useful for understanding our complex discipline and perhaps breaking through some of the boundaries that contribute to regulating and limiting its potentialities. We apply these theoretical lenses to critically examine how dominant discourses come to be accepted as consensus in occupational therapy and how such discourses may only be the product of a powerplay that silences oppositional voices. 


\section{On the Perils of Dogmatic Consensual Discourses}

Despite the activist and reformist pre-war orientation of our profession, which emerged as a response to industrialization and the urbanization of society (Taff \& Balubal, 2021), authoritative discourses and oppressive forces similar to those of a warfare regime remain and persist in regulating occupational therapy practice by enacting, as a police order of the discipline, a form of 'disciplinary propaganda.'

\section{A persistent military fetish}

Notwithstanding the activist orientation of pre-war occupational therapy (Youngson, 2019), our profession owes much of its rapid expansion to the military force in which it got massively deployed during the First and Second World Wars (Bryden \& McColl, 2003). Through war efforts, the early use of arts and crafts and mental health activism were rapidly institutionalized in our profession (Levine, 1987), overcoming its esthetic and reformist ideals to serve Nation States' political and military interests. In that sense, occupational therapy ultimately, and perhaps involuntarily, contributed to the 'chain of command' of the military force, by enabling the smoothest return to continued economic productivity and accelerating the 'adjustment' of veterans to civil life (Bryden \& McColl, 2003).

This military background is only one aspect of the history of occupational therapy; it did not concern the majority of occupational therapists, who remained civilians (Frank, 1992). However, we argue that its political influence is still present in our discipline, as in other health disciplines (Perron et al., 2010). Rather than overt militarization, this influence is mostly thought of symbolically and is seen through the underlying threads of regulation inside and outside the profession (e.g. authoritative discourses, hierarchy, control). Drawing on its contribution to military efforts, occupational therapy has been increasingly recognized by biomedical authorities as a component of the rehabilitation of wounded soldiers (Bryden \& McColl, 2003), thus allowing for its further integration in health and social services. This recognition represented a win in the struggle against biomedical authorities (Rogers, 1982), who 'policed' who could and could not participate in the esthetic regime of health care. Despite struggling to establish itself as an autonomous health profession, occupational therapy remains extensively regulated and is still accountable to biomedical authorities (Freeman et al., 2009).

By reproducing biomedicine's police order controlling who can and cannot provide medical acts, our discipline is in fact playing the same game against its own 'political' threats by protecting those who have a part in the profession and rejecting those who do not. As a police order (Rancière, 1998), this regulation is embedded in all the subtle forces and processes that enact borders (symbolic or real), like the gates at the entrance to a city, to decide who is admitted to the profession and who is not, what there is to speak about and what is deemed irrelevant. Through various managerial and professional accountability expectations, over the years this regulation penetrated almost every aspect of occupational therapy (Freeman et al., 2009). Similar to warfare regimes which no longer use wide-scale demonstrations of violence but which penetrate molecular aspects of everyday life through various technologies of control (Mbembe, 2019), this all-encompassing regulation meticulously polices every aspect of our practice. In this case, our profession's specific attention to everyday life may not be completely foreign to this miniaturization of the regulation that is programmed over its practice (Rudman, 2012). In occupational therapy, 
technologies of control may include intrusive instruments that practise surveillance (audits and inspections), which serve to render occupational therapists hypervisible to their regulatory bodies and thus more easily controlled.

\section{An anonymous and invisible authority}

As the military governance morphed into civil institutions, the engagement of most occupational therapists as bureaucrats in widespread government institutions is based on very similar grounds (Aldrich \& Rudman, 2020): both require obedience to a strict set of rules while debates and resistance are consistently repressed or silenced. Drawing on a regime of silence and the principle of loyalty (Gagnon \& Perron, 2020), free public speech in such organizations remains highly controlled, if not entirely prohibited, especially when it criticizes the organization's wrongdoing, unethical or illegal practices (Perron et al., 2020). For example, the expectation that members of a professional association support the association's positions (e.g. "CAOT expects its members to support CAOT"; Canadian Association of Occupational Therapists, 2018) may be in conflict with the members' ability to criticize it publicly.

Unfortunately, the authoritarianism typical of the military regime has not been replaced by more autonomy; instead, it paved the way for an even more pernicious form of authority (Mackey, 2007). In complex bureaucratic environments, like those in which most occupational therapists habitually work (Aldrich \& Rudman, 2020), forms of authority are not more overt but more anonymous, invisible, and alienated (Fromm, 1955). According to Fromm (1955, p. 149), "[...] the mechanism through which the anonymous authority operates is conformity". Therefore, obedience to the chain of command has been supplanted by another form of irrational authority, that of compulsive conformity.

As long as there are visible forms of irrational authority, conflict and rebellion are possible. However, occupational therapists cannot rebel against overt forms of authority when they do not know who they are obeying. The development of a hierarchical vision of the profession is imposed through professional standards and competencies by national and international associations, each enforcing their regime of norms through university programs that are asked to develop rigid and standardized academic curricula (Whiteford \& Wilcock, 2001). Under the guise of progress and the scientific status of occupational therapy, the enforcement of this type of authority makes it even more challenging for occupational therapists to recognize how it actually restricts their autonomous practice. Following the same authority, professional regulatory bodies reinforce those norms through accountability expectations and obligations whereas widespread government institutions dictate the models of practice and roles that occupational therapists can play in these organizations (Freeman et al., 2009).

Such overt authorities can rarely be dislocated from covert authorities imposing other regimes of norms, as well as various moralities that establish what is desirable or not (Mackey, 2007). Based on a contingent division of what is perceptible (sensible) as meaningful (Gourgues, 2013), these discursive authorities install rigid constraints on the development of our discipline, both externally (biomedicine, neoliberalism, or individualism) and internally (drawing exclusively on occupation-based theories/models). External constraints pertain to the dominant conception of health, orienting individual interventions toward biomedical aspects of the human body (Farias \& Rudman, 2019b), rather than collective and social aspects of human life. Internally, this affects the 
mainstream conception of occupation, imposing a focus on 'adjusting' the individual to the dominant capitalist order which requires participating actively in a productive economy and self-care (Kronenberg et al., 2011) rather than enjoying, for example, freeform leisure time and non-(re)productive pleasure for its own sake.

While external influences may be easier to identify, influences from within occupational therapy may be subtler, and therefore, more difficult to challenge (Holmes et al., 2007). Nevertheless, both influences (internal or external) require an 'heteronomous' form of obedience by its subjects - an act of submission and subjugation to external demands rather than 'autonomous' obedience implying an affirmation of oneself (Fromm, 1981). Refusing to conform to this anonymous authority, therefore, demands a conscious effort to be aware of its insidious influence on practice.

\section{A hierarchy of knowledge}

The underlying threads of the military structure further replicated themselves, at least symbolically, in the knowledge development processes of our profession. In a discipline like occupational therapy, dominant discourses are reinforced when specific forms of knowledge are established as consensus (Hammell, 2009a) while other voices are relegated to marginal or fringe spaces. Although endorsed as the favored path for the development of occupational therapy, the evidence-based movement imposed a linear and hierarchical knowledge production process (Bennett \& Bennett, 2000) that actively competed with how knowledge has been historically produced in our discipline and forced the rejection of diverse forms of knowledge developed through the creativity that characterized the arts-and-crafts movement (Morley et al., 2011). Drawing exclusively on evidence-based discourse implies agreeing to submit to the 'dogma' of the hierarchy of evidence (Holmes et al., 2006a), in which randomized controlled trials are considered the highest indicator of knowledge quality (Tomlin \& Borgetto, 2011); theoretical and experiential perspectives, on the other hand, are deemed irrelevant, if not rejected outright (Lambert, 2020).

Like a police order, evidence-based dogma functions by excluding alternative worldviews (Arendt, 1972) and dictating what can be done, written, said, or thought (Holmes et al., 2006b). By reducing human lives to common, measurable factors, evidence-based dogma also works to exclude 'the part who have no part' and does not allow them to be recognized. The widespread enthusiasm surrounding evidence-based medicine is a demonstration of a hierarchical authority strictly enforcing standardized protocols and interventions (Hanemaayer, 2020). The competitiveness of the professional 'market' imposed by the neoliberal discourse and financial restraints (Rappolt et al., 2002), which gave rise to evidence-based discourses (Holmes et al., 2006a), forced occupational therapy to replicate the marketization of its knowledge in order to remain as distinct as possible from other professions (Morley \& Rennison, 2011). This marketization is observed in the branding and copyrighting of standardized assessment tools, intervention protocols and practice guidelines which serve to privatize the knowledge in occupational therapy. In this way, it ensures that not everyone can become occupational therapists, or even use occupational therapy knowledge, the conditions of which are determined by those who 'own' this knowledge. Marketization also means that occupational therapists can only practise if they are a part of the market, i.e. employed by those who own the means of production and have the power to determine how this practice will be deployed. 
As a collateralization of the military influence, it is interesting to observe how a form of 'scientific nationalism' has imposed itself discursively on the dissemination structures of occupational therapy knowledge. Though not the case with every health discipline, most influential occupational therapy journals are attached to a specific country or sociopolitical background (e.g. Nordic or Asian regions). While editorial policies are not applied equally strictly in all journals, some do prioritize knowledge produced by researchers from their specific region. Whether or not they publish articles primarily from their region, the naming of journals by country/region in and of itself implies a form of nationalism. Although it could be a way to prevent Western perspectives from being over-represented, this trend induced a form of chauvinism and a normative judgement, where some forms of knowledge, based on the place from which they were drawn, are more valuable than others in informing how we think about and develop the discipline. It is difficult to pinpoint what, in nationalism like this, truly serves the interests of occupational therapy, and what maintains historical narratives about which country victoriously contributed most to the development of the profession.

\section{A disciplinary propaganda}

Occupational therapy is often presented as a harmless and intrinsically beneficial health profession (Dige, 2009). As with other health disciplines, like nursing (Radcliffe, 2000), it seems impossible to imagine how a health profession like occupational therapy could be harmful, oppressive, or even violent (Foth, 2013). With the widespread consensus surrounding its intrinsic 'goodness,' it is even more challenging, if not downright impossible, to develop oppositional perspectives to such esthetic regimes. Confronted by an irreducible optimism, it becomes inconceivable to wage an 'internal' critique from within a closed system, contributing to a shrinkage of political space in the profession, despite efforts to inject political thought into education (Irvine-Brown et al., 2020).

The dogmatic ways of thinking about our discipline can be embellished as much as possible (through professional standards or competencies) but it can be argued that dominant discourses represent a form of disciplinary propaganda (Holmes et al., 2006a) with which occupational therapists must conform, whether they are aware of it or not. From this pattern of conformity emerges a new sort of morality, where virtue means to be like the rest and vice is to be different (Fromm, 1955). The overwhelming enthusiasm surrounding the current consensual order should be taken seriously as blindly conforming to it (and refusing to be disruptive), which could deprive our discipline of a wide range of situations seen in the field (Morley et al., 2011). Such situations include alternative ways of doing and being that remain poorly understood and under-theorized, especially when the occupations do not conform with mainstream thought (Bukhave \& Creek, 2021), such as illegal, deviant or unhealthy occupations (Kiepek et al., 2019) as well as underground/invisible (Beagan et al., 2018) or discrete practices (Aldrich \& Rudman, 2020).

Instead, dominant discourses require its members to be obedient and submit to its set of rules and norms in order to be included in the field. To any knowledge must be added almost compulsively - the label 'occupational' if it is to be accepted not only by legitimate authorities but also by our peers (Hammell, 2017), which is a form of language 'policing.' Otherwise this knowledge may be seen as unintelligible. The discursive division between occupational science and occupational therapy (Lunt, 1997; Morley et al., 2011) is in 
constant tension with the expectation that occupational therapy draws mostly on occupationbased theories (Vallée, 2020). Such a division - often reinstated by competing editorial policies - makes it increasingly difficult and almost unthinkable to develop philosophical reflections on occupational therapy without embracing occupational concepts or drawing on occupation-based theories/models. Thus, the label 'occupational' acts as a floating signifier (Mehlman, 1972) that pervades the way we think and speak about occupational therapy, which can no longer be seen and understood otherwise, despite its inherent contradictions, and dismisses alternative ways of thinking about occupations.

\section{Oppressive forces in the politics of occupation}

As Hammell (2009a) exposed, our current understanding of the relations between occupations, healthy living, and environment is not neutral but is mostly the result of a political process regulated by those in positions of authority, inside or outside the profession. Consensus occurs when pre-existing discourses, such as those surrounding mainstream occupational concepts (Hammell, 2009a), are preached as being 'true' or 'real' while counter-hegemonic ways of life are silenced, made invisible, or seen as delinquent (Kronenberg et al., 2011). It is becoming increasingly evident that the political processes underlying the construction of consensus in occupational therapy were in fact built on unequal social, historical, economic and professional structures, producing arbitrary categories of differences (Kronenberg et al., 2011). Dissenting voices exposed the theoretical imperialism in occupational therapy knowledge, based on Western, White, female, upper-class, able-bodied, Anglo-Saxon, Northern, and heteronormative perspectives (Guajardo et al., 2015; Hammell, 2011).

Depending on language, class, gender or ethnocultural perspectives, rigid conceptualizations of 'occupation' can even be oppressive for some (Abberley, 1995). Needless to say, 'occupation' for peoples living in occupied and colonized territories (Mbembe, 2019) does not have the beneficial and intrinsically 'good' connotation (Emery-Whittington, 2021) that most occupational therapists seem to endorse in the Global North (Hammell, 2015). Although North-South relationships are mainly driven by militarization (Mbembe, 2019), we do not often hear voices critical of militarism (Cook, 1977), to which occupational therapy owes much of its rapid expansion (Frank, 1992), alongside capitalism and colonialism. In contexts other than upper-class, Anglo-Saxon cultures, 'occupation' is mostly understood as productive occupations, such as work and self-care (Persson \& Erlandsson, 2002), which reinforces the prevailing ableist, classist and heteronormative discourse based on rigid normative categories of difference (Kronenberg et al., 2011) as well as neoliberal values that translate into a vocabulary promoting productivity and performance (Hammell, 2009b).

Fixed understandings of occupations also tend to overshadow more marginal and transgressive ways of living, being and thinking, such as those which do not perpetuate capitalist, reproduction-oriented temporalities, also referred to as 'ReproTime.' Queer critiques addressed the tendency of ReproTime to oppress other ways of life, which can hardly be understood by staying within a heteronormative mindset (Murray et al., 2017). To illustrate the oppressive nature of ReproTime requires looking for queer perspectives (queer 'ways of life' or 'QueerTime') which resist and oppose heteronormative temporalities, essentially entrenched in a narrative of work/family time, capital accumulation and 'generational succession' (Warner, 1991). These perspectives may help to illustrate the 'part 
who have no part' of our profession, who continue to exist outside the official discourse. In occupational therapy, the part who have no part are all those of us who refuse to 'adjust' to the current social order, which they recognize as unequal, and hence refuse to perpetuate the status quo or conform to a disciplinary propaganda that continues to favor the dominant order. Our collective responsibility is to challenge this consensus because of its intrinsic inequality and absence of neutrality, rather than blindly conforming to it.

\section{On the Obligation of Disobedience and Dissensus}

Now that we have exposed how consensual discourses in occupational therapy often rely on compulsive conformity and can ultimately become dogmatic or oppressive, we will turn to disobedience and dissensus as critical responses to overcome such a dominant order.

\section{Learning to become disobedient thinkers}

As a profession that rapidly expanded through post-war efforts, it seemed logical to turn to the thought of post-war thinkers like Fromm and Rancière to imagine how occupational therapy might evolve differently in the future. What we learned from the First and Second World Wars is that when a society marginalizes dissent and debates in favor of a dogmatic and strict obedience to a fabricated regime of truth, this can be extraordinarily destructive. What they also taught us is that democracy 'secures' our right to resist but that, in the face of unjust laws, this right becomes an obligation (Cervera-Marzal, 2013). Despite this responsibility, occupational therapy did not learn how to become a disobedient profession (Geddes et al., 2009). As an extension of the military effort, occupational therapists were socialized to obey the rules where any form of disobedience or transgression of the norm were deemed to be a vice or mental illness (Levine, 2005), disempowering those who question the authority in place. The policing further imposed by biomedicine and the evidence-based movement led to an even more docile and obedient profession, as with other health disciplines (Holmes et al., 2006b).

As the level of education required to become an occupational therapist increased (sometimes including a master's or doctoral degree), we could have expected a greater propensity to disobedience, as has been observed among doctors, lawyers or teachers (Falcón y Tella, 2004). Perhaps because such endeavors remain silenced or ignored (Perron et al., 2020), it is difficult to say how many occupational therapists perform disobedient thought or to cite concrete examples of such practice in our profession. The 'Social Transformation Through Occupation' (Rudman et al., 2019), 'Social Occupational Therapy' (Malfitano et al., 2014) and 'Social Change Agency' (Carrier et al., 2021) scholarships certainly contain examples of initiatives that disrupt the status quo. While some initiatives do express a form of dissensus or disobedience, these two notions are often not addressed explicitly as these initiatives struggle to establish themselves in the face of dominant biomedical, neoliberal and individualistic discourses (Farias \& Rudman, 2019a).

Rather, what is observed is a greater expectation that occupational therapists conform to specific norms that allow them to meet the needs of the professional market (Rappolt et al., 2002). It is not easy to disagree with this presumptive 'good', especially when these discourses are dictated by those in positions of authority. However, obedience becomes 'pathological' when it depends on irrational authorities (Fromm, 1955), for the 
sake of conformity. Taken to the extreme, this is how the history of occupational therapy as we know it may eventually end: with the ultimate act of obedience.

\section{Confronting an esthetic regime}

Exposing oppressive forces in our discipline means confronting the esthetic regime imposed by discursive authorities doggedly defending occupational therapy's intrinsic goodness. This confrontation is especially difficult to accept for those who embrace dominant discourses as a dogma (Holmes et al., 2006a). Because it makes the 'obedient' thinker one with the authority which shares its omnipotent power, conformity creates a strong sense of safety and protection (Fromm, 1965). As professional, managerial and political authorities decide on and watch over all of the obedient occupational therapist's behavior, the latter is never left alone and does not have to fear being wrong. It certainly takes courage to stray away from a dominant discourse in occupational therapy but it is also a necessary step toward freedom of thought and practice (Fromm, 1965). By departing from the expected behavior, disobedience means rejecting the comforting security provided by being part of a herd-like sanctioned institution. In that sense, disobedient thought can be viewed by the group of likeminded individuals as a lack of loyalty, treason or a betrayal that jeopardizes the smooth functioning of institutions (Perron, 2013).

To disobey in occupational therapy therefore requires having the courage to tolerate the discomfort of being alone and isolated and to endure the possibility of being mistaken. But courage alone is not enough; it also requires freeing ourselves from the bonds that tie us to the prevailing status quo that stabilizes a discipline (Fromm, 1981). Despite efforts to reduce occupational therapy to its 'therapeutic' virtue (Levine, 1987), critical voices persisted in pointing to its political nature (Pollard \& Sakellariou, 2014). Disobedient thought like this is a necessary step toward freedom of thought, just as freedom is a precondition of disobedience. Fromm (1981, p. 9) puts it clearly: "A person can become free through acts of disobedience by learning to say no to power. . If I am afraid of freedom, I cannot dare to say 'no,' . . . any social, political, and religious system which proclaims freedom, yet stamps out disobedience, cannot speak the truth". In that sense, freedom of thought in occupational therapy cannot exist without disobedient thought, and vice versa.

\section{Seeking a dis-alienating and genuinely humane conscience}

If radically escaping dominant discourses and disrupting the status quo is not easy, a first step for occupational therapists could be to question the type of authority which they obey but, most importantly, reveal the conscience underlying their ways of thinking and acting. If they could always act accordingly, occupational therapists would be relying purely on their humane conscience and their actions would always conform with the rules of Humanity. Fromm (1955) observed that it is not always possible to act in accordance with our humane conscience, especially because of the unhealthy and unequal patterns reproduced by the societies in which we live. For Fromm, the goal of a healthy society should be to feed humans' capacity to love, work creatively, develop reason, and have a sense of self, while unhealthy societies transform them into instruments of use and exploitation, thereby depriving them of a sense of self, inasmuch as they submit to an external authority. In The Sane Society Fromm (1955), shows that post-industrial, capitalist 
societies are actually insane, imposing an 'authoritarian' regime that alienates humans from nature, work, and each other, and even from their own humanity.

In this critical piece, Fromm (1955) condemns the inaction of health professionals who, instead of challenging the inhumane conscience underlying unhealthy societies, are simply trying to help humans adapt and 'adjust' to it. The current focus on individual biomedical aspects of health and occupations might not allow occupational therapists to challenge what 'everyday life' actually means and how returning to everyday life may in fact be unhealthy, oppressive or violent (Gerlach et al., 2018). The outcome of such miniaturization of everyday life may even become unethical or unprofessional when the current order induces silence in the wake of inhumane situations. If occupational therapists fear they do not have the ability to think, act or speak freely under the current status quo, it might be because they are accepting the influence of an authoritarian conscience. It could also mean that they are obeying irrational forms of authority, perpetuated through compulsive conformity, rather than turning to rational authorities based on values of equity and a plurality of voices (Rancière, 2010). Instead of being critics of an unhealthy society, occupational therapists might involuntarily become apologists for the status quo (Levine, 2005), thereby betraying their own humane conscience. On the contrary, occupational therapists must distance themselves from the authoritarian conscience of the unhealthy society and disobey its irrational authority, which favors the few over the majority. This means seeking 'rational' authorities, in accordance with a healthy society. In this context, disobedient thought itself constitutes an act of reason that opens up the possibility for occupational therapists to see how things could be different.

\section{Becoming 'common sense rebels'}

This critique speaks to various calls in our discipline for a socially-responsive agenda that seeks to transform the structures oppressing individuals by limiting their occupational potentialities (Cunningham et al., 2020; Farias \& Rudman, 2019a; Rudman et al., 2019). Instead of reproducing individualistic practices that fail to tackle oppression and social injustices (Gerlach et al., 2018), occupational therapists could enact disobedient thought by becoming what Levine (2005), drawing on Fromm, conceptualized as 'common sense rebels.' For Levine (2005, p. 125), "[...] common sense rebels see society that has become increasingly dehumanizing, worshipping consumption, production, and technology, and thus glorifying speed, control, standardization, and efficiency. They urge us to neither adapt nor rebel destructively, but instead rebel in a life-affirming manner". As with the anti-militarism movement that rallied against the 'wholesale' production of disabilities caused by never-ending wars (Cook, 1977), it meant revolting against the military fetishes still so closely connected to the rapid expansion of occupational therapy (Frank, 1992). Any institution or system which, to sustain itself, is reliant on other humans being disabled or injured sufficiently regularly cannot be considered humane or ethical. Because of the same deleterious effects of capitalism and colonialism on the production of disabilities (Abberley, 1987; Russell, 2019), occupational therapists cannot afford to remain silent and silenced by the current order.

Unlike other thinkers (Žižek, 2008), Fromm and Rancière refuse to become virtuous philosophers indicating precisely how occupational therapists should act and in what circumstances, other than insisting that those who suffer from an unequal police order must act collectively against it. More precisely, Rancière (2009) encourages us to leave the 
door open to disagreement and conflict, as any political activity would be ineffective if it does not interrupt what is taken for granted. The task is not only to prevent the continual shrinkage of political space in our discipline. It is also esthetic insofar as it requires a reconfiguration of what is perceptible (sensible) so that the dominant order is disrupted by those who demand not only to exist but also to be seen and heard as if they were equal. As Rancière (1998, p. 12) argues: "There is only the order of domination or the disorder of revolt". Accordingly, this means that occupational therapists may ultimately only have the choice between the comfort and order of conforming to dominant discourses, or the discomfort and disorder stemming from revolt.

This dichotomy can certainly be problematized as it could arguably seem to maintain a binary vision foreclosing on pluralist perspectives that continue to exist. However, what it means for Rancière is that there should be no compromise if we decide to strive for equality. Anything that is put in the way of equality should be sufficient to trigger a revolt, even if this means destabilizing common sense by creating 'disordered' polemical spaces where the part who have no part exist as equals. Even if this paper was intended to be provocative, it is by no means an invitation to accept seductive and reductionist 'all-ornothing' responses. By exposing some of the limitations of the current order in occupational therapy, we arrive at the conclusion that responses may perhaps be found somewhere in the middle, which is itself a space of conflict and confrontation (Rose, 1992).

\section{Conclusion}

Challenging consensual discourses in occupational therapy is no easy task because the terms by which anyone might levy a critique are controlled by those who are accepted as scientific authorities. We do not consider ourselves to be authorities; rather, we are simply attempting to address the dogmatic ways in which consensus is built in our discipline and demonstrate that the current order does not leave room for a plurality of ways of life. Drawing on the work of Erich Fromm and Jacques Rancière, we offer an overview of how such consensual discourses may obscure and silence the expression of dissenting voices. We argue that occupational therapists should be aware of the complex and subtle processes that jeopardize their autonomy and seek to challenge them thoughtfully. By that, we mean the often dogmatic consensual discourses and the disciplinary propaganda that shape the status quo. We believe that, by using disobedient thought instead of perpetuating the rules of an unhealthy capitalist society, occupational therapists have the obligation to express dissent against these consensual discourses and mount a theoretical and critical revolt. As authorities become more and more anonymous and invisible, our collective ability to disobey is even more compromised since we cannot know what order we are obeying in the first place. The risks associated with disobedience and dissensus are not negligible but nor are the reprisals, the accusations of treason and betrayal, and the rejection and distrust based on what is viewed as a lack of loyalty. While we do not propose concrete ways for occupational therapists to enact disobedience or dissensus, we agree with Fromm and Rancière who argue for the need to act collectively by interrogating and challenging the authorities which we obey as well as their underlying conscience. In doing so, we raise some questions: What is our collective goal as a professional body? Can we really say that the systems in which we operate produce the conditions for these goals to be achieved? By blindly obeying the authority and rejecting any dissensus, are we not reproducing these 
unequal and unhealthy structures? If we really tend toward a healthy society, why should we accept the terms imposed by an unhealthy society? Can we really afford to perpetuate these inequalities knowing that we will be asked to go further and mitigate them? How can we transgress the regime of rules, norms and truths regulating our practice? If one truly cares about the development of occupational therapy, disobedience and dissensus are perhaps some of the ways forward. By giving rise to healthier thought, they could be what will save occupational therapy from bringing about its own demise.

\section{References}

Abberley, P. (1987). The concept of oppression and the development of a social theory of disability. Disability, Handicap \& Society, 2(1), 5-19. http://dx.doi.org/10.1080/02674648766780021.

Abberley, P. (1995). Disabling ideology in health and welfare: the case of occupational therapy. Disability \& Society, 10(2), 221-232. http://dx.doi.org/10.1080/09687599550023660.

Aldrich, R. M., \& Rudman, D. L. (2020). Occupational therapists as street-level bureaucrats: leveraging the political nature of everyday practice. Canadian Journal of Occupational Therapy, 87(2), 137-143. http://dx.doi.org/10.1177/0008417419892712.

American Occupational Therapy Association - AOTA. (2020). AOTA 2020 occupational therapy code of ethics. The American Journal of Occupational Therapy, 74(Suppl. 3), 1-13. http://dx.doi.org/10.5014/ajot.2020.74S3006.

Arendt, H. (1972). Les origines du totalitarisme: le système totalitaire. Paris: Seuil.

Beagan, B. L. (2020). Commentary on racism in occupational science. Journal of Occupational Science, 18(3), 1-4. http://dx.doi.org/10.1080/14427591.2020.1833682.

Beagan, B. L., Chapman, G. E., \& Power, E. (2018). The visible and invisible occupations of food provisioning in low income families. Journal of Occupational Science, 25(1), 100-111. http://dx.doi.org/10.1080/14427591.2017.1338192.

Bennett, S., \& Bennett, J. W. (2000). The process of evidence-based practice in occupational therapy: informing clinical decisions. Australian Occupational Therapy Journal, 47(4), 171-180. http://dx.doi.org/10.1046/j.1440-1630.2000.00237.x.

Browning, G. (2010). Badiou, Balibar and Rancière: re-thinking emancipation. Contemporary Political Theory, 9(4), 508-510. http://dx.doi.org/10.1057/cpt.2010.9.

Bryden, P., \& McColl, M. A. (2003). The concept of occupation: 1900 to 1974. In M. A. McColl, M. Law, D. Stewart, L. Doubt, N. Pollock \& T. Krupa (Eds.), Theoretical basis of occupational therapy (pp. 2737). Thorofare: SLACK Incorporated.

Buchanan, I. (2010). A dictionary of critical theory. Oxford: Oxford University Press.

Bukhave, E. B., \& Creek, J. (2021). Occupation through a practice theory lens. Journal of Occupational Science, 28(1), 95-101. http://dx.doi.org/10.1080/14427591.2020.1812105.

Canadian Association of Occupational Therapists - CAOT. (2018). Code of ethics. Ottawa. Retrieved in 2020, December 16, from https://www.caot.ca/site/pt/codeofethics?nav=sidebar

Carrier, A., Éthier, A., Beaudoin, M., Hudon, A., Bédard, D., Jasmin, E., \& Verville, F. (2021). Acting as Change Agents: Insight Into Québec Occupational Therapists' Current Practice. Canadian Journal of Occupational Therapy, 88(2), 173-181. http://dx.doi.org/10.1177/0008417421994367.

Cervera-Marzal, M. (2013). Désobéir en démocratie: la pensée désobéissante, de Thoreau à Martin Luther King. França: Aux Forges de Vulcain.

Clark, F. (2006). One person's thoughts on the future of occupational science. Journal of Occupational Science, 13(2-3), 167-179. http://dx.doi.org/10.1080/14427591.2006.9726513.

Cook, B. W. (1977). Female support networks and political activism: Lillian Wald, Crystal Eastman, Emma Goldman. Chrysalis, 17(1), 43-61. 
Cunningham, M., Warren, A., Pollard, N., \& Abey, S. (2020). Enacting social transformation through occupation: a narrative literature review. Scandinavian Journal of Occupational Therapy, 1(1), 1-20. http://dx.doi.org/10.1080/11038128.2020.1841287.

Deranty, J. P. (2003). Jacques Rancière's contribution to the ethics of recognition. Political Theory, 31(1), 136-156. http://dx.doi.org/10.1177/0090591702239444.

Dige, M. (2009). Occupational therapy, professional development, and ethics. Scandinavian Journal of Occupational Therapy, 16(2), 88-98. http://dx.doi.org/10.1080/11038120802409754.

Eisenberg, N. R. (2012). Post-structural conceptualizations of power relationships in physiotherapy. Physiotherapy Theory and Practice, 28(6), 439-446. http://dx.doi.org/10.3109/09593985.2012.692585.

Emery-Whittington, I. G. (2021). Occupational justice-colonial business as usual? indigenous observations from aotearoa New Zealand: la justice occupationnelle : sous régime colonial comme d'habitude? observations d'autochtones d'aotearoa en Nouvelle-Zélande. Canadian Journal of Occupational Therapy, 88(2), 153-162. http://dx.doi.org/10.1177/00084174211005891.

Falcón y Tella, M. J. (2004). Civil disobedience. Boston: Martinus Nijhoff Publishers. http://dx.doi.org/10.1163/9789047414094.

Farias, L., \& Rudman, D. L. (2019a). Challenges in enacting occupation-based social transformative practices: a critical dialogical study. Canadian Journal of Occupational Therapy, 86(3), 243-252. http://dx.doi.org/10.1177/0008417419828798.

Farias, L., \& Rudman, D. L. (2019b). Practice analysis: critical reflexivity on discourses constraining socially transformative occupational therapy practices. British Journal of Occupational Therapy, 82(11), 693-697. http://dx.doi.org/10.1177/0308022619862111.

Farias, L., Rudman, D. L., Pollard, N., Schiller, S., Malfitano, A. P. S., Thomas, K., \& van Bruggen, H. (2019c). Critical dialogical approach: a methodological direction for occupation-based social transformative work. Scandinavian Journal of Occupational Therapy, 26(4), 235-245. http://dx.doi.org/10.1080/11038128.2018.1469666.

Foth, T. (2013). Nurses, medical records and the killing of sick persons before, during and after the Nazi regime in Germany. Nursing Inquiry, 20(2), 93-100. http://dx.doi.org/10.1111/j.1440-1800.2012.00596.x.

Frank, G. (1992). Opening feminist histories of occupational therapy. The American Journal of Occupational Therapy, 46(11), 989-999. http://dx.doi.org/10.5014/ajot.46.11.989.

Freeman, A. R., McWilliam, C. L., MacKinnon, J. R., DeLuca, S., \& Rappolt, S. G. (2009). Health professionals' enactment of their accountability obligations: DOIng the best they can. Social Science \& Medicine, 6977), 1063-1071. http://dx.doi.org/10.1016/j.socscimed.2009.07.025.

Fromm, E. (1955). The sane society. United Kingdom: Routledge.

Fromm, E. (1965). Escape from freedom. New York: Avon Books.

Fromm, E. (1981). On disobedience and other essays. New York: Seabury Press.

Gagnon, M., \& Perron, A. (2020). Whistleblowing: a concept analysis. Nursing \& Health Sciences, 22(2), 381-389. http://dx.doi.org/10.1111/nhs.12667.

Geddes, E. L., Salvatori, P., \& Eva, K. W. (2009). Does moral judgement improve in occupational therapy and physiotherapy students over the course of their pre-licensure training? Learning in Health and Social Care, 8(2), 92-102. http://dx.doi.org/10.1111/j.1473-6861.2008.00205.x.

Gerlach, A. J., Teachman, G., Laliberte-Rudman, D., Aldrich, R. M., \& Huot, S. (2018). Expanding beyond individualism: engaging critical perspectives on occupation. Scandinavian Journal of Occupational Therapy, 25(1), 35-43. http://dx.doi.org/10.1080/11038128.2017.1327616.

Gourgues, G. (2013). Sans part. In I. Casillo, R. Barbier, L. Blondiaux, F. Chateauraynaud, J. M. Fourniau, R. Lefebvre, N. Neveu \& D. Salles (Eds.), Dictionnaire critique et interdisciplinaire de la participation (pp. 2268-5863). Paris: GIS Démocratie et Participation.

Grenier, M. L. (2020). Cultural competency and the reproduction of White supremacy in occupational therapy education. Health Education Journal, 79(6), 633-644. http://dx.doi.org/10.1177/0017896920902515. 
Guajardo, A., Kronenberg, F., \& Ramugondo, E. L. (2015). Southern occupational therapies: emerging identities, epistemologies and practices. South African Journal of Occupational Therapy, 45(1), 3-10. http://dx.doi.org/10.17159/2310-3833/2015/v45no1a2.

Guba, E. G., \& Lincoln, Y. S. (1998). Competing paradigms in qualitative research. In N. K. Denzin \& Y. S. Lincoln (Eds.), The landscape of qualitative research: theories and issues (pp. 195-220). Thousand Oaks: Sage.

Hammell, K. W. (2009a). Sacred texts: a sceptical exploration of the assumptions underpinning theories of occupation. Canadian Journal of Occupational Therapy, 76(1), 6-13. http://dx.doi.org/10.1177/000841740907600105.

Hammell, K. W. (2009b). Self-Care, productivity, and leisure, or dimensions of occupational experience? rethinking occupational "categories". Canadian Journal of Occupational Therapy, 76(2), 107-114. http://dx.doi.org/10.1177/000841740907600208.

Hammell, K. W. (2011). Resisting theoretical imperialism in the disciplines of occupational science and occupational therapy. British Journal of Occupational Therapy, 74(1), 27-33. http://dx.doi.org/10.4276/030802211X12947686093602.

Hammell, K. W. (2015). Respecting global wisdom: enhancing the cultural relevance of occupational therapy's theoretical base. British Journal of Occupational Therapy, 78(11), 718-721. http://dx.doi.org/10.1177/0308022614564170.

Hammell, K. W. (2017). Critical reflections on occupational justice: toward a rights-based approach to occupational opportunities: réflexions critiques sur la justice occupationnelle: vers une approche des possibilités occupationnelles fondée sur les droits. Canadian Journal of Occupational Therapy, 84(1), 4757. http://dx.doi.org/10.1177/0008417416654501.

Hanemaayer, A. (2020). The impossible clinic: a critical sociology of evidence-based medicine. Vancouver: UBC Press.

Hewlett, N. (2007). Badiou, Balibar, Rancière: re-thinking emancipation. London: Continuum.

Holmes, D., \& Gagnon, M. (2018). Power, discourse, and resistance: poststructuralist influences in nursing. Nursing Philosophy, 19(1), e12200. http://dx.doi.org/10.1111/nup.12200.

Holmes, D., Gastaldo, D., \& Perron, A. (2007). Paranoid investments in nursing: a schizoanalysis of the evidencebased discourse. Nursing Philosophy, 8(2), 85-91. http://dx.doi.org/10.1111/j.1466-769X.2007.00302.x.

Holmes, D., Perron, A., \& O’Byrne, P. (2006a). Evidence, virulence, and the disappearance of nursing knowledge: A critique of the evidence-based dogma. Worldviews on Evidence-Based Nursing, 3(3), 95102. http://dx.doi.org/10.1111/j.1741-6787.2006.00058.x.

Holmes, D., Murray, S. J., Perron, A., \& Rail, G. (2006b). Deconstructing the evidence-based discourse in health sciences: truth, power and fascism. International Journal of Evidence-Based Healthcare, 4(3), 180186. http://dx.doi.org/10.1097/01258363-200609000-00003.

Holmes, D., Roy, B., \& Perron, A. (2008). The use of postcolonialism in the nursing domain: colonial patronage, conversion, and resistance. Advances in Nursing Science, 31(1), 42-51. http://dx.doi.org/10.1097/01.ANS.0000311528.73564.83.

Irvine-Brown, L., Tommaso, A. D., Malfitano, A. P. S., \& Molineux, M. (2020). Experiences of occupational therapy education: contexts, communities and social occupational therapy. Cadernos Brasileiros de Terapia Ocupacional, 28(1), 330-342. http://dx.doi.org/10.4322/2526-8910.ctoARF1931.

Kiepek, N. C., Beagan, B., Rudman, D. L., \& Phelan, S. (2019). Silences around occupations framed as unhealthy, illegal, and deviant. Journal of Occupational Science, 26(3), 341-353. http://dx.doi.org/10.1080/14427591.2018.1499123.

Kronenberg, F., Pollard, N., \& Ramugondo, E. (2011). Introduction: courage to dance politics. In F. Kronenberg, N. Pollard \& D. Sakellariou (Eds.), Occupational therapies without borders: toward an ecology of occupation-based practices (pp. 1- 16). London: Churchill Livingstone Elservier.

Lambert, R. (2020). Editorial: strategy for BJOT development. British Journal of Occupational Therapy, 83(8), 485-487. http://dx.doi.org/10.1177/0308022620943100.

Levine, B. (2005). Mental illness or rebellion? Ethical Human Psychology and Psychiatry, 7(2), 125-129. http://dx.doi.org/10.1891/1559-4343.7.2.125. 
Levine, R. E. (1987). The influence of the arts-and-crafts movement on the professional status of occupational therapy. The American Journal of Occupational Therapy, 41(4), 248-254. http://dx.doi.org/10.5014/ajot.41.4.248.

Lunt, A. (1997). Occupational science and occupational therapy: negotiating the boundary between a discipline and a profession. Journal of Occupational Science, 4(2), 56-61. http://dx.doi.org/10.1080/14427591.1997.9686421.

Mackey, H. (2007). 'Do not ask me to remain the same': foucault and the professional identities of occupational therapists. Australian Occupational Therapy Journal, 54(2), 95-102. http://dx.doi.org/10.1111/j.1440-1630.2006.00609.x.

Malfitano, A. P. S., Lopes, R. E., Magalhães, L., \& Townsend, E. A. (2014). Social occupational therapy: conversations about a Brazilian experience. Canadian Journal of Occupational Therapy, 81(5), 298-307. http://dx.doi.org/10.1177/0008417414536712.

Mbembe, A. (2019). Necropolitics. London: Duke University Press.

Mehlman, J. (1972). The "floating signifier": from Lévi-Strauss to Lacan. Yale French Studies, (48), 10-37. http://dx.doi.org/10.2307/2929621.

Morley, M., \& Rennison, J. (2011). Marketing occupational therapy: everybody's Business. British Journal of Occupational Therapy, 74(8), 406-408. http://dx.doi.org/10.4276/030802211X13125646371040.

Morley, M., Atwal, A., \& Spiliotopoulou, G. (2011). Has occupational science taken away the occupational therapy evidence base? a debate. British Journal of Occupational Therapy, 74(10), 494-497. http://dx.doi.org/10.4276/030802211X13182481842065.

Murray, S. J., Holmes, D., \& Foth, T. (2017). Introduction: RadSex in theory and in practice. In D. Holmes, S. J. Murray \& T. Foth (Eds.), Radical sex between men: assembling desiring-machines (pp. 122). Oxford: Routledge. http://dx.doi.org/10.4324/9781315399546-1.

Nicholls, D. A. (2017). The end of physiotherapy. New York: Routledge. http://dx.doi.org/10.4324/9781315561868.

Occupational Therapy Australia - OTAUS. (2014). Code of ethics. Victoria. Retrieved in 2020, December 16, from https://otaus.com.au/publicassets/f3bceaea-49ff-e811-a2c2b75c2fd918c5/OTA\%20Code\%20of\%20Ethics\%202014.pdf

Perron, A. (2013). Nursing as 'disobedient' practice: care of the nurse's self, parrhesia, and the dismantling of a baseless paradox. Nursing Philosophy, 14(3), 154-167. http://dx.doi.org/10.1111/nup.12015.

Perron, A., Rudge, T., \& Gagnon, M. (2020). Hypervisible nurses: effects of circulating ignorance and knowledge on acts of whistleblowing in health. Advances in Nursing Science, 43(2), 114-131. http://dx.doi.org/10.1097/ANS.0000000000000311.

Perron, A., Rudge, T., Blais, A. M., \& Holmes, D. (2010). The politics of nursing knowledge and education critical pedagogy in the face of the militarization of nursing in the war on terror. Advances in Nursing Science, 33(3), 184-195. http://dx.doi.org/10.1097/ANS.0b013e3181e093bc.

Persson, D., \& Erlandsson, L. K. (2002). Time to reevaluate the machine society: post-industrial ethics from an occupational perspective. Journal of Occupational Science, 9(2), 93-99. http://dx.doi.org/10.1080/14427591.2002.9686497.

Pollard, N., \& Sakellariou, D. (2014). The occupational therapist as a political being. Cadernos de Terapia Ocupacional da UFSCar, 22(3), 643-652. http://dx.doi.org/10.4322/cto.2014.087.

Pollard, N., \& Sakellariou, D. (2017). Occupational therapy on the margins. World Federation of Occupational Therapists Bulletin, 73(2), 71-75. http://dx.doi.org/10.1080/14473828.2017.1361698.

Radcliffe, M. (2000). Doctors and nurses: new game, same result. British Medical Journal, 320(7241), 1085. http://dx.doi.org/10.1136/bmj.320.7241.1085.

Rancière, J. (1998). Disagreement: Politics and Philosophy. Minneapolis: University of Minnesota Press.

Rancière, J. (2009). Les démocraties contre la démocratie. In A. L. Gauthier \& V. Lefebvre-Faucher (Eds.), Démocratie dans quel état? (pp. 66-70). Montréal: Écosociété.

Rancière, J. (2010). Dissensus: on politics and aesthetics. London: Continuum. 
Rancière, J., \& Panagia, D. (2000). Dissenting words: a conversation with Jacques Rancière. Diacritics, 30(2), 113-126. http://dx.doi.org/10.1353/dia.2000.0016.

Rappolt, S., Mitra, A. L., \& Murphy, E. (2002). Professional accountability in restructured contexts of occupational therapy practice. Canadian Journal of Occupational Therapy, 69(5), 293-302. http://dx.doi.org/10.1177/000841740206900505.

Reid, H. A. J., Hocking, C., \& Smythe, L. (2019). The making of occupation-based models and diagrams: history and semiotic analysis. Canadian Journal of Occupational Therapy, 86(4), 313-325. http://dx.doi.org/10.1177/0008417419833413.

Rogers, J. C. (1982). Order and disorder in medicine and occupational therapy. The American Journal of Occupational Therapy, 36(1), 29-35. http://dx.doi.org/10.5014/ajot.36.1.29.

Rose, G. (1992). The broken middle: out of our ancient society. Oxford: Wiley-Blackwell.

Rudman, D. L. (2012). Governing through occupation: shaping expectations and possibilities. In G. Whiteford \& C. Hocking (Eds.), Occupational science: society, inclusion, participation (pp. 100-116). New Jersey: Wiley-Blackwell http://dx.doi.org/10.1002/9781118281581.ch8.

Rudman, D. L., \& Aldrich, R. (2016). “Activated, but stuck”: applying a critical occupational lens to examine the negotiation of long-term unemployment in contemporary socio-political contexts. Societies, 6(3), 1-17. http://dx.doi.org/10.3390/soc6030028.

Rudman, D. L., Dennhardt, S., Fok, D., Huot, S., Molke, D., Park, A., \& Zur, B. (2008). A vision for occupational science: reflecting on our disciplinary culture. Journal of Occupational Science, 15(3), 136146. http://dx.doi.org/10.1080/14427591.2008.9686623.

Rudman, D. L., Pollard, N., Craig, C., Kantartzis, S., Piškur, B., Algado Simó, S., van Bruggen, H., \& Schiller, S. (2019). Contributing to social transformation through occupation: experiences from a think tank. Journal of Occupational Science, 26(2), 316-322. http://dx.doi.org/10.1080/14427591.2018.1538898.

Russell, M. (2019). Capitalism and disability: selected writings by Marta Russell. Chicago: Haymarket Books.

Taff, S. D., \& Balubal, G. (2021). Philosophy and occupational therapy: informing education, research, and practice. Thorofare: Slack Incorporated.

Tomlin, G., \& Borgetto, B. (2011). Research pyramid: a new evidence-based practice model for occupational therapy. The American Journal of Occupational Therapy, 65(2), 189-196. http://dx.doi.org/10.5014/ajot.2011.000828.

Vallée, C. (2020). Mettre l'occupation au cœur de nos actions. Canadian Journal of Occupational Therapy, 87(4), 233-239. http://dx.doi.org/10.1177/0008417420952317.

Warner, M. (1991). Introduction: fear of a queer planet. Social Text, (29), 3-17.

Whiteford, G. E., \& Wilcock, A. A. (2001). Centralizing occupation in occupational therapy curricula: imperative of the new millennium. Occupational Therapy International, 8(2), 81-85. http://dx.doi.org/10.1002/oti.134.

Youngson, B. (2019). Craftivism for occupational therapists: finding our political voice. British Journal of Occupational Therapy, 82(6), 383-385. http://dx.doi.org/10.1177/0308022619825807.

Žižek, S. (2008). Violence. New York: Picador.

\section{Author's Contributions}

Pier-Luc Turcotte and Dave Holmes were responsible for the original conception of the analysis and the selection of theoretical frameworks. Pier-Luc Turcotte completed the critical analysis and interpretation of the concepts, organized the sources and drafted the manuscript. Dave Holmes contributed extensively to the analysis and interpretation, and thoroughly revised the manuscript. All authors approved the final version of the text. 


\title{
Funding Source
}

Pier-Luc Turcotte and Dave Holmes would like to thank the Canadian Institutes of Health Research (CIHR) for funding.

\section{Corresponding author}

Pier-Luc Turcotte

e-mail: Pier-Luc.Turcotte@USherbrooke.ca

\section{Section editor}

\author{
Profa. Dra. Ana Paula Serrata Malfitano
}

